\title{
Intake of stimulant foods is associated with development of parasomnias in children
}

\author{
Ingestão de alimentos estimulantes está associada ao desenvolvimento de parassonias \\ em crianças
}

Fabiana Ruotolo, Lucila B. F. Prado, Vanessa R. Ferreira, Gilmar F. Prado, Luciane B. C. Carvalho

\begin{abstract}
Objective: To verify if nighttime feeding habits can influence parasomnia in children. Method: Seven private and four public Elementary Schools took part in the study. A total of 595 Sleep Disturbance Scale for Children were distributed to the parents of children aged from 7 to 8 years. Data of dietary recall, starting time to school, physical activity, and nutritional status were studied. Results: Of the 226 questionnaires completed, $92(41 \%)$ reported parasomnia. Girls had 2.3 times more the chance to parasomnia than boys. Children who consumed stimulant foods had 2.6 times more chance to have parasomnia than those of children who consumed non-stimulant foods. There were no difference between parasomnia and no-parasomnia groups in food type ( $p=0.78)$ or timing of last meal before bedtime $(p=0.50)$. Conclusion: Our findings suggest that intake of stimulant foods is associated with development of parasomnia in children.
\end{abstract}

Keyword: children, sleep, parasomnias, stimulant food, dietary habits.

\section{RESUMO}

Objetivo: Verificar se hábitos de alimentação noturna influenciam parassonias em crianças. Método: Sete escolas privadas e quatro públicas, de Ensino Fundamental, fizeram parte do estudo. Um total de 595 Escalas de Distúrbio do Sono para Crianças foram distribuídas para os pais de crianças entre 7 e 8 anos. Dados de recordatório alimentar, período escolar, atividade física e estado nutricional foram estudados. Resultados: Dos 226 questionários preenchidos, 92 (41\%) relataram presença de parassonias. Meninas tiveram 2,3 vezes mais chance de parassonias e crianças que consumiram alimentos estimulantes tiveram 2,6 vezes mais chance de parassonias em relação àquelas que consumiram alimentos não estimulantes. Não houve diferença entre os grupos em relação ao tipo de alimento ( $p=0,78)$ ou horário da última refeição antes de ir para a cama $(p=0,50)$. Conclusão: Nossos achados sugerem que a ingestão de alimentos estimulantes está associada com o desenvolvimento de parassonias em crianças.

Palavra-chave: crianças, sono, parassonias, alimentação estimulante, hábitos alimentares.

The current lifestyle of children and adolescents, immersed in modern communication and entertainment technologies, has shortened sleep duration and led to modifications in dietary habits, with unfavorable impacts on health ${ }^{1,2}$.

Quantitative reductions in sleep are associated with metabolic and nutritional derangements, and evidence suggests that individuals who sleep less are more likely to become obese ${ }^{3,4,5}$. The type and timing of meals influence metabolite levels, substrate use, and hormone production ${ }^{6}$. Sleep deprivation is particularly harmful to growing children and adolescents. Inadequate sleep habits affect cognitive and physical performance ${ }^{7,8,9}$, induce daytime sleepiness, alter mood, and lead to an increased predisposition to systemic disease ${ }^{10,11}$.
Children are particularly affected by parasomnia, undesirable physical phenomena or experiences that occur while sleeping, while falling asleep, or on arousal ${ }^{12}$. Parasomnia may be associated with familial factors, use of certain drugs, auditory stimulus in the sleep environment, and obstructive sleep apnea syndrome $e^{13,14}$.

Around 2 years of age, a genetic predisposition to sleep state dissociation and activation in sleep of subcortical Central Pattern Generators (CPGs), may trigger patterns of abnormal motor behavior that are characterized as confusional arousals, sleep terrors, or sleep walking. Down regulation of descending cortical to subcortical inhibitory projections that have GABAergic properties or a relative deficiency of serotonergic inhibition at the level of the spinal cord may play a key

Universidade Federal de São Paulo, Departamento de Medicina, Setor Neuro-Sono, Sao Paulo SP, Brazil.

Correspondence: Lucila B. F. Prado; Rua Claudio Rossi, 394; 01547-000 São Paulo SP, Brasil; E-mail: neuro.sono.unifesp@gmail.com

Conflict of interest: There is no conflict of interest to declare.

Received 11 June 2015; Received in final form 15 September 2015; Accepted 06 October 2015. 
role in disinhibiting brainstem or spinal cord CPGs, the consequence of which is NREM parasomnias ${ }^{15}$.

Research on dietary habits and their association with parasomnia is scarce, but studies have shown a negative effect of caffeinated beverages on sleep, including reductions in total sleep duration, prolonged sleep latency, and changes in the duration of "light" and "deep" sleep"

Within this context, the objective of this study was to ascertain whether nighttime feeding habits can influence sleep, and especially parasomnia, in children.

\section{METHOD}

\section{Population and setting}

This was a cross-sectional, observational study. The lead investigator contacted 40 Elementary Schools (18 public, 22 private). Of these, seven private and four public schools accepted to take part in the study. The sample size was calculated at 225 (5\% sampling error, 95\% confidence interval), for a $17 \%$ prevalence of parasomnia in the pediatric population ${ }^{17}$. The study project was approved by the Research Ethics Committee. The legal guardians of all children involved in the study signed the Consent Form for participation.

\section{Procedures}

A total of 595 questionnaires were distributed to the parents and legal guardians of children aged from 7 to 8 years (second and third grades). Of these, 398 were completed directly in the presence of the interviewer or at home and then returned to the lead investigator. Overall, 226 questionnaires were deemed valid and included (female subjects were ultimately more prevalent, at 52\%) (Table 1); 172 were excluded due to incorrect data, presence of chronic or acute illness, neurological disease, or use of medication.

\section{Sleep questionnaire}

Children were administered the Sleep Disturbance Scale for Children - SDSC (adapted to and validated for the Brazilian population) and classified as presence or absence of parasomnia ${ }^{18,19}$.

The SDSC is a 26-item questionnaire designed to assess symptoms of sleep disorders, sleep breathing disorder - SBD (score $>7$ ), difficulty initiating and maintaining sleep - DIMS (score $>22$ ), disorders of arousal - DA (score > 12), sleepwake transition disorder - SWTD (score > 24), disorder of excessive somnolence - DES (score > 20), and sleep hyperhydrosis - SHY (score $>8$ ). Parasomnia was defined by the presence of manifestations indicative of these conditions at least once a week. The items used for detection of parasomnia were (as described in the original SDSC): 1) "The child startles or jerks parts of the body while falling asleep"; 2) "The child shows repetitive actions such as rocking or head banging while falling asleep"; 3) "The child experiences vivid dream-like scenes while falling asleep"; 4) "The child has frequent twitching or jerking of legs while asleep or often changes position during the night or kicks the covers off the bed"; 5) "You have observed the child sleepwalking"; 6) "You have observed the child talking in his/her sleep"; 7) "The child grinds teeth during sleep"; 8) "The child wakes from sleep screaming or confused so that you cannot seem to get through to him/her"; and 9) "The child has nightmares which he/she doesn't remember the next day".

Table 1. Demographic data of children with or without parasomnias.

\begin{tabular}{|c|c|c|c|c|}
\hline & Total & No parasomnia $\mathrm{n}(\%)$ & Parasomnia n (\%) & $P$ \\
\hline & 226 & $134(59)$ & $92(41)$ & \\
\hline Girls & $116(51.3)$ & $69(51.5)$ & $47(52)$ & \\
\hline Boys & $110(48.7)$ & $65(48.5)$ & $45(48)$ & 0.94 \\
\hline Starting time to school & $222(98)$ & $133(99)$ & $89(97)$ & \\
\hline Morning & $107(48)$ & $71(53)$ & $36(40)$ & 0.21 \\
\hline Afternoon & $98(44)$ & $56(42)$ & $42(47)$ & \\
\hline Full-Time & $13(6)$ & $6(4.5)$ & $7(8)$ & \\
\hline Intermediate & $4(2)$ & $0(0)$ & $4(4.5)$ & \\
\hline Ethnicity & 218 & $129(59.2)$ & $89(40.8)$ & \\
\hline caucasian & $201(92)$ & $123(95.3)$ & $78(87.6)$ & 0.24 \\
\hline afro-Brazilian & $17(7.8)$ & $6(4.7)$ & $11(12.4)$ & \\
\hline $\mathrm{BMI}$ & $182(80)$ & $107(58.8)$ & $75(41.2)$ & \\
\hline Low BMI for age & $10(5)$ & $9(11)$ & $1(1)$ & 0.9 \\
\hline Adequate BMI for age & $99(54)$ & $56(55)$ & $43(53)$ & \\
\hline Overweight & $44(24)$ & $23(53.3)$ & $21(47.7)$ & \\
\hline Obesity & $29(16)$ & $19(23)$ & $10(10)$ & \\
\hline Physical activity & 224 (99) & $132(98.5)$ & $92(100)$ & \\
\hline Yes & $154(69)$ & $97(73)$ & $57(62)$ & 0.09 \\
\hline No & $70(31)$ & $35(26)$ & 35 (38) & \\
\hline
\end{tabular}

BMI : body mass index. 


\section{Dietary recall}

A dietary recall was conducted with the objective of characterizing nighttime feeding habits (both regarding the type of food consumed and the timing of meals before bedtime) and collecting data on ethnicity and academic activities (class schedule).

The dietary recall survey took into account the type of food (solids only, fluids only, both solids and fluids) consumed before bedtime. All foods and beverages were classified as stimulant (coffee, mate or black tea, chocolate milk, cocoa, and caffeinated soft drinks, including guarana and cola) or non-stimulant.

The type and quantity of each food consumed was recorded, and foods were classified into groups as follows: carbohydrates, fats, proteins, or a balanced meal (containing one food from each of the aforementioned groups). When subjects consumed both solids and fluids during the same meal, this intake was classified under a mixed food group.

Two categories were defined for timing of nighttime meals, using 1-hour cutoffs: between 6 p.m. and midnight or after midnight.

\section{Starting time to school}

Starting time to school is defined as morning (7:30 a.m. to 12 p.m.), afternoon (1 p.m. to 5:30 p.m.), full-time (8 a.m. to 5 p.m.) or intermediate (11 a.m. to 3 p.m.).

\section{Physical activity and nutritional status}

The study questionnaire also included items designed to collect data on physical activity, weight and height, so as to enable calculation of nutritional status in accordance with World Health Organization (WHO) body mass index (BMI) growth charts ${ }^{20}$.

\section{Statistical analysis}

TheChi-squareTest wasused for comparison of databetween the parasomnia and non-parasomnia groups for the following independent categorical variables: sex, ethnicity, starting time to school (morning, afternoon, intermediate, or full-time as defined above), BMI (low BMI-for-age, adequate BMI-for-age, overweight, or obese), and physical activity (yes/no), as well as for the following diet-related categorical variables: bedtime, timing of last meal before bedtime, food type (solids, fluids, or both), and food class (stimulant or non-stimulant), taking sex into account. Logistic Regression was performed for presence or absence of the dichotomous variable presence of parasomnia. The significance level was set at $\mathrm{p}<0.05$.

\section{RESULTS}

Of the 226 questionnaires completed, 92 (41\%) reported presence of DA or SWTD at least once weekly, thus establishing a diagnosis of parasomnia.
The presence of parasomnia was not associated with gender ( $p=0.24)$, ethnicity ( $p=0.24)$, starting time to school ( $p=0.21)$, or BMI $(p=0.9$; Table 1$)$. Children who engaged in physical activity were more likely to experience parasomnia $(62 \%)$ than those who were not physically active $(38 \% ; p=0.09)$.

There were no differences between the parasomnia and no-parasomnia groups in terms of food type (solids, fluids, or both $)(\mathrm{p}=0.78)$ or timing of last meal before bedtime $(\mathrm{p}=0.50$; Table 2). Of the children who experienced parasomnia, $45 \%$ consumed stimulant foods, whereas $55 \%$ did not $(p=0.04)$. The most commonly consumed stimulant food was chocolate milk, followed by soft drinks.

Analysis of the timing of the last meal before bedtime and bedtime itself showed that children who had dinner later (at 10 p.m.) had a tendency $(\mathrm{p}=0.06)$ to be more likely to go to bed later (at midnight).

An adjusted logistic regression model was constructed with the variables gender $(p=0.02)$, BMI $(p=0.16)$, and type of stimulant food ( $p=0.008$; Table 3 ). Girls had 2.3 times more the chance to parasomnia than boys. Children who consumed stimulant foods had 2.6 times more chance to have parasomnia than those of children who consumed non-stimulant foods.

\section{DISCUSSION}

The odds of parasomnia in children who consumed stimulant foods or beverages were 2.6 greater the chance of children who consumed non-stimulant foods.

Table 2. Type and time of intake food of children with or without parasomnias.

\begin{tabular}{lccc}
\hline & $\begin{array}{c}\text { No parasomnias } \\
\mathrm{n}(\%)\end{array}$ & $\begin{array}{c}\text { Parasomnias } \\
\mathrm{n}(\%)\end{array}$ & $\mathrm{P}$ \\
\hline Total & $134(59.3)$ & $92(40.7)$ & \\
226 & & & \\
Timing of last meal before & 224 & 92 & \\
bed time & & & \\
6 p.m to 6:59 p.m & $15(7)$ & $8(8.7)$ & 0.50 \\
7 p.m to 7:59 p.m & $51(23)$ & $20(22)$ & \\
8 p.m to 8:59 p.m & $67(30)$ & $27(29)$ & \\
9 p.m to 9:59 p.m & $53(24)$ & $18(19.5)$ & \\
10 p.m to10:59 p.m & $29(13)$ & $15(16)$ & \\
11 p.m to 11:59 p.m & $8(3.5)$ & $3(3)$ & \\
after 0 a.m & $1(0.4)$ & $1(1.1)$ & \\
Types of food & 201 & 89 & \\
solid food & $43(21)$ & $21(23.6)$ & 0.78 \\
Fluid food & $5(2.5)$ & $2(2)$ & \\
Both solid and fluid food & $153(76)$ & $66(74)$ & \\
Food & 203 & 94 & \\
stimulants & $75(37)$ & $42(45)$ & 0.04 \\
no stimulants & $128(63)$ & $52(55)$ & \\
\hline
\end{tabular}




\begin{tabular}{|c|c|c|c|c|c|c|c|c|c|}
\hline \multicolumn{10}{|c|}{ Variables in the Equation } \\
\hline & & \multirow{2}{*}{ B } & \multirow{2}{*}{ SE } & \multirow{2}{*}{ Wald } & \multirow{2}{*}{$d f$} & \multirow{2}{*}{ P. } & \multirow{2}{*}{ OR } & \multicolumn{2}{|c|}{$95 \% \mathrm{Cl}$ for $\mathrm{OR}$} \\
\hline & & & & & & & & Lower & Upper \\
\hline \multirow[t]{4}{*}{ Step $22^{a}$} & Sex1 & .832 & .366 & 5.171 & 1 & .023 & 2.299 & 1.122 & 4.711 \\
\hline & $\mathrm{BMI} 0$ & -20.768 & 15724.201 & .000 & 1 & .999 & .000 & .000 & \\
\hline & Stim & .970 & .374 & 6.721 & 1 & .010 & 2.638 & 1.267 & 5.494 \\
\hline & Constant & -1.073 & .317 & 11.432 & 1 & .001 & .342 & & \\
\hline
\end{tabular}

Sex1: girls; BMI: body mass index; BMI 0: adequate for age; Stim: children consumed stimulants food; B: measure of variables in equation; SE: sampling error; df: degree of freedom; OR: odds ratio; Cl: confidence interval.

The most prevalent stimulant foods reported in our sample were chocolate milk and carbonated soft drinks, both of which contain caffeine.

Caffeine is present in many foods, including coffee beans, tea leaves, chocolate, cocoa beans, cola, nuts, and guarana berries, and it is often added to beverages and, to a lesser extent, to drug formulations. Approximately $80 \%$ of the general population consumes or has consumed caffeine at some point ${ }^{21}$.

The stimulant effects of caffeine are not due to direct actions on the central nervous system, but to indirect stimulation by inducing blockade of another neuromodulator, adenosine, which usually exerts a calming effect on brain and spinal cord neurons ${ }^{22}$. Caffeine increases the amount of adrenaline and noradrenaline secreted by the adrenal medull ${ }^{23}$ and increases central noradrenaline synthesis and turnover in the cerebral cortex, consequently exerting a stimulatory effect and boosting wakefulness ${ }^{24}$.

In a U.S. study, $41 \%$ of school-aged children were found to consume at least one caffeinated beverage per day. These children reported sleeping 20 minutes fewer than children who did not consume caffeine. Furthermore, caffeine was not associated with sleep latency, but rather with total sleep duration ${ }^{25}$.

Another study found an association between wake-up time in adolescents and a tendency toward intake of caffeinated beverages and fast food, as well as a decreased intake of dairy products. Adolescents who retired to bed earlier led healthier lifestyles ${ }^{26}$.

We were unable to find any studies on the potential association between nighttime feeding habits and parasomnia, but a study of adolescents found that those who slept $<8$ hours obtained a higher proportion of their energy intake from fat and a lower proportion from carbohydrates as compared with those who slept 8 hours a day on average. Furthermore, snacks tended to account for $\geq 475 \mathrm{kcal}$ of their daily energy intake, with an even greater prevalence among girl $\mathrm{s}^{27}$.

Studies of healthy men and women have reported major associations between decreased sleep quantity, dietary patterns, and risk of obesity ${ }^{28}$.

In a study of 27,983 women, those who slept 10 hours or longer were found to have inadequate dietary patterns, similar to those of subjects who slept $<6 \mathrm{~h}^{29}$.

This association was also observed in a sample of 3304 young Japanese women: those who slept later tended to have their meals later, skip meals more often, not eat for longer, and eat while watching television, not only at breakfast but also at lunch and dinner ${ }^{30}$.

The main limitation of this study was the use of questionnaires completed by the parents or guardians of participants. Despite the widespread popularity of this method, it can fail to provide the most accurate information, as most parents work outside the home and may be unaware of their children's true dietary habits. Furthermore, parents and children slept in different rooms in the majority of cases, which precludes close observation of sleep patterns and feeding. Finally, it is possible that parents may have failed to perceive all but the most marked parasomnia, as milder phenomena would not have roused them from sleep.

Our findings suggest that intake of stimulant foods is associated with development of parasomnias in children. Nevertheless, emotional and psychological aspects involving family dynamics and academic life should be considered in the pathogenesis of parasomnia, and might even prompt changes in dietary habits. 
1. Calamaro CJ, Mason TBA, Ratcliffe SJ. Adolescents living the 24/7 lifestyle: effects of caffeine and technology on sleep duration and daytime functioning. Pediatrics. 2009;123(6):e1005-10. doi:10.1542/peds.2008-3641

2. Gradisar M, Gardner G, Dohnt H. Recent worldwide sleep patterns and problems during adolescence: a review and meta-analysis of age, region and sleep. Sleep Med. 2011;12(2):110-8. doi:10.1016/j.sleep.2010.11.008

3. Spiegel K, Leproult R, Tasali E, Penev P, VanCauter E. Sleep curtailment results in decreased leptin levels and increased hunger and appetite. Sleep. 2003;26:A174.

4. Nedeltcheva AV, Kilkus JM, Imperial J, Kasza K, Schoeller DA, Penev PD. Sleep curtailment is accompanied by increased intake of calories from snacks. Am J Clin Nutr. 2008;89(1):126-33. doi:10.3945/ajcn.2008.26574

5. Crispim CA, Zalcman I, Da'ttilo M, Padilha HG, Edwards B, Waterhouse $\mathrm{J}$ et al. The influence of sleep and sleep loss upon food intake and metabolism. Nut Res Rev. 2007;20(2):195-212. doi:10.1017/S0954422407810651

6. Jenkins DJA. Carbohydrate tolerance and food frequency. Br J Nutr. 1997;77(Suppl S1):S71-81. doi:10.1079/BJN19970105

7. Carvalho LBC, Prado LBF, Silva L, Almeida MM, Silva TA, Vieira $\mathrm{CM}$ et al. Cognitive dysfunction un children with sleep disorders. Arq Neuropsiquiatr. 2004;62(2A):212-6. doi:10.1590/S0004-282X2004000200004

8. Carvalho LBC, Prado LBF, Silva L, Almeida MM, Silva TA, Lora MI et al. Cognitive dysfunction un children with sleep disordered breathing. J Child Neur. 2005;20(5):400-4. doi:10.1177/08830738050200050101

9. Moran CA, Carvalho LBC, Prado LBF, Prado GF. Sleep disorders and starting time to school impair balance in 5-years old children. Arq Neuropsiquiatr. 2005;63(3A):571-6. doi:10.1590/S0004-282X2005000400003

10. Curcio G, Ferrara M, De Gennaro DL. Sleep loss, learning capacity and academic performance. Sleep Med Rev. 2006;10(5):323-37. doi:10.1016/j.smrv.2005.11.001

11. Spruyt K, Molfese DL, Gozal D. Sleep duration, sleep regularity, body weight, and metabolic homeostasis in school-aged children. Pediatrics. 2011;127(2):e345-52. doi:10.1542/peds.2010-0497

12. American Academy of Sleep Medicine. The international classification of sleep disorders: diagnostic and coding manual. 2nd edition. Westchester: American Academy of Sleep Medicine; 2005.

13. Petit D, Touchette E, Tremblay RE, Boivin M, Montplaisir J. Dyssomnias and parasomnias in early childhood. Pediatrics. 2007;119(5):e1016-25. doi:10.1542/peds.2006-2132

14. Guilleminault C, Eldridge LF, Simmons B, Dement CW. Sleep apnea in eight children. Pediatrics. 1976;58(1):23-30.

15. Kotagal S. Pathophysiology of parasomnias. In: Ivanenko A, Kothare SV. Parasomnias: clinical characteristics and treatment. New York: Springer; 2013. p. 9-14.

16. Rétey JV, Adam M, Khatami R, Luhmann U F O, Jung HH, Berger $W$ et al. A genetic variation in the adenosine A2A receptor gene (ADORA2A) contributes to individual sensitivity to Caffeine effects on sleep. Clin Pharmacol Ther. 2007;81(5):692-8. doi:10.1038/sj.clpt.6100102

17. Rosen GM, Mahowald MW. Disorders of arousal in children. In Sheldon SH, Ferber R, Kryger MH. Principles and practice of pediatric sleep medicine. Philadelphia: Elsevier Saunders; 2005. p. 293-304.

18. Bruni O, Ottaviano S, Guidetti V, Romoli M, Innocenzi M. The Sleep Disturbance Scale for Children (SDSC). Construction and validation of an instrument to evaluate sleep disturbances in childhood and adolescence. J Sleep Res 1996;5(4):251-61. doi:10.1111/j.1365-2869.1996.00251.x

19. Ferreira VR, Carvalho LBC, Ruotolo F, Morais JF, Prado LBF, Prado GF. Sleep Disturbance Scale for Children: translation, cultural adaptation, and validation. Sleep Med. 2009;10(4):457-63. doi:10.1016/j.sleep.2008.03.018

20. World Health Organization. [Accessed June 15, 2013]. Available from: http://www.who.int/growthref/en

21. McArdle WD, Katch FI, Katch VL. Nutrição para o desporto e o exercício. Rio de Janeiro: Guanabara Koogan; 2001. p. 306-11.

22. Sökmen B, Armnstrong LE, Kraemer WS, Casa DJ, Dias JC, Judelson DA et al. Caffeine use in sports: considerations for the athlete. J Strength Cond Res. 2008;22(3):978-96. doi:10.1519/JSC.0b013e3181660cec

23. Papadelis C, Kourtidou-Papadeli C, Vlachogiannis E, Skepastianos P, Bamidis P, Maglaveras N et al. Effects of mental workload and caffeine on cathecolamines and blood pressure compared to performance variations. Brain Cogn.2003;51(1):143-54. doi:10.1016/S0278-2626(02)00530-4

24. Smith A, Brice C, Nash J, Rich N, Nutt DJ. Caffeine and centranoradrenaline: effects on mood, cognitive performance, eye movements and cardiovascular function. J. Psychopharm.2003;17(3):283-92. doi:10.1177/02698811030173010

25. Mindell JA, Meltzer LJ, Carskadon AM, Chervin RD. Developmental aspects of sleep hygiene: findings from the 2004 National Sleep Foundation Sleep in America Poll. Sleep Med. 2009;10(7):771-9. doi:10.1016/j.sleep.2008.07.016

26. Fleig D, Randler C. Association between chronotype and diet in adolescents based on food logs. Eat Beh 2009;10(2):115-8. doi:10.1016/j.eatbeh.2009.03.002

27. Weiss A, Xu F, Storfer-Isser A, Thomas A, Levers-Landis CE, Redline $S$. The association of sleep duration with adolescents, fat and carbohydrate consumption. Sleep. 2010;33(9):1201-9.

28. Nedeltcheva AV, Kilkus JM, Imperial J, Kasza K, Schoeller DA, Penev PD. Sleep curtailment is accompanied by increased intake of calories from snacks. Am J Clin Nutr. 2009;89(1):126-33. doi:10.3945/ajcn.2008.26574

29. Sangmi K, DeRoo LA, Sandler DP.Eating patterns and nutritional characteristics associated with sleep duration. Public Health Nutr. 2011;14(5):889-95. doi:10.1017/S136898001000296X

30. Sato-Mito N, Sasaki S, Murakami K, Okubo H, Takahashi Y, Shibata $S$ et al. The midpoint of sleep is associated with dietary intake and dietary behavior among young Japanese women. Sleep Med. 2011;12(3):289-94. doi:10.1016/j.sleep.2010.09.012 